\title{
Digital Wisdom in Research Work
}

\author{
Anna Matysek \\ ORCID 0000-0003-1042-7895 \\ Institute of Culture Studies, Faculty of Humanities \\ University of Silesia in Katowice, Poland \\ Jacek Tomaszczyk \\ ORCID 0000-0002-9199-659X \\ Institute of Culture Studies, Faculty of Humanities \\ University of Silesia in Katowice, Poland
}

\begin{abstract}
Purpose/Thesis: The article focuses on digital wisdom, defined by Marc Prensky as the ability to use modern computer technology wisely to improve thinking and decision-making and to better share the results of research. The aim of this article is to present some of the digital tools that increase the efficiency of scientific research and facilitate conceptual work, information retrieval, note-taking and writing up of research.

Approach/Methods: The research process comprised several stages, each of which focused on a specific tool that directly increases work efficiency and performs functions beyond human capabilities. Results and conclusions: The latest digital tools are equipped with features that increase efficiency at all stages of the research process. They speed up the completion of a task (e.g. searching for information) and illuminate the relationships between documents or individual concepts that researchers themselves would not register (e.g. through the visualization of data and information).

Originality/Value: The skillful use of modern digital tools is a fundamental element of digital wisdom as computer programs and Web applications significantly broaden human perception and cognitive capabilities.
\end{abstract}

\section{Keywords}

Digital tools. Digital wisdom. Information retrieval. Note-taking. Research work.

Received: 30 September 2020. Reviewed: 11 November 2020. Revised: 16 November 2020.

Accepted: 26 November 2020.

The power of the unaided mind is highly overrated. Without external aids, memory, thought, and reasoning are all constrained. But human intelligence is highly flexible and adaptable, superb at inventing procedures and objects that overcome its own limits. The real powers come from devising external aids: it is things that make us smart (Norman, 1993, 43)

\section{Introduction}

A hammer, an axe, a microscope, a computer, a spreadsheet - what do these things have in common? They are all tools: physical objects that help us accomplish a task. In a broader sense, all tools are a means to an end. We distinguish different types of tools, e.g. moving 
tools, cutting tools, perception tools, data and information manipulation tools, which serve different purposes. The purpose of a tool is to enhance its user's abilities to make them stronger, more precise, more efficient or wiser. Our ancestors used handheld tools mainly to exert physical force on objects. While the tools we use today are more developed, we still take advantage of other handheld tools, to increase not our physical strength but rather our intellectual power. They include books, mobile phones, tablets and computers. Although they are physical objects, their functions are not performed by the material they are made of nor by their outer structure. Their utility resides in their content (information) and its meaning, or in the processes they carry out (a computer). We also use digital tools, such as computer programs and mobile applications.

Tools and technology have played a crucial role in human development, altering our species' relationship with our environment. Increasingly advanced tools have been developed. Starting with digging sticks, wooden spears, fire, basic garments and shelter, later advancing to the development of arts, music and language, then the fabrication of ships, engines and vehicles, culminating in the recent creation of digital technologies. They have revolutionized the structure of our bodies, expanded the capabilities of our minds, and given birth to human societies of unparalleled size and power (Currier, 2017, xiv).

Information is one of the major forces that fueled both human and societal development. For thousands of years people stored information in their brains as evolutionary pressures adapted them to store large amounts of botanical, zoological, topographical and social information. However, with the emergence of complex societies, a completely new type of information emerged: numbers. Numerical data, which human brains were not adapted to store and process, started to be used to register information about people's incomes and possessions, taxes, payments, debts, fines, as well as about discounts and exemptions. Such immense quantities of abstract data were impossible to memorize, so if states were to grow and prosper, it was imperative to find a new method of registering all of these transactions. The first attempt to overcome the limits of human memory was made by the Sumerians (3500-3000 BC) who invented a system for storing and processing information outside our brains. The system was writing. It overcame the limitations of the human brain and paved the road for the establishment of cities, kingdoms and empires (Harari, 2015, 136-137). But in our digitally-driven world, the tool of writing itself needs to be enhanced in order to accommodate the growing needs of writers, researchers, and scientists.

The digital tools of today are designed to deal with huge amounts of information. Databases, spreadsheets, task and project managers, communications platforms, note-taking applications, reference managers are used in order to store, process and share data, to control information flow, and generally speaking, to increase users' productivity. Information is derived from data, organized and interpreted in a given context. However, sheer information is not enough. We want knowledge, which is a result of processing information through synthesis, internalization, analysis and reduction (Sosińska-Kalata, 2016, 9). What do we do with knowledge? We apply it to make decisions, solve problems or interpret events: "When knowledge is put into practice that's when wisdom is born within a person" (Mwanandeke, n.d.).

The current information age is characterized by pervasive technology and the use of information on an unprecedented scale, as we gather, represent, store, and retrieve unimaginable amounts of data. Efficient tools are needed to manage information and to turn 
it into knowledge. Our computers are fast, our databases are voluminous, we can readily access information resources from any place through a range of devices, and yet something is still missing. More than ever, we need mechanisms to cope with the overabundance of content; we need more quality than quantity, more attention than distraction, and more wisdom than information. If we are to live in a digital era, we must attain digital wisdom.

Digital wisdom is a term coined by Marc Prensky to describe "integrating the technology of our times into our thinking and decision making, doing it wisely, and sharing the results" (Prensky, 2012a, 47). Digital wisdom refers to the ability to combine the activities of the mind with the operations of the computer to obtain the most intelligent answers to questions (Shaughnessy et al., 2010, 30). Human mind is able to reflect, see patterns, create categories and associations, and intuit. Machines excel at storing, processing and analyzing huge quantities of data. They can also be of great help in decision-making processes as human judgment is fallible when assessing risk in complex situations (Wilkinson-Ryan, 2020). Digital tools bridge these two worlds, the world of mankind and the world of computers. The expected result is extending human intellect and gaining digital wisdom:

Digital wisdom arises from the combination of the mind and digital tools; what the unenhanced mind loses by outsourcing mundane tasks will be more than made up for by the wisdom gained. Wisdom, and particularly practical wisdom, must be understood in light of the digital enhancements that make it stronger (Prensky, 2012b, 211).

John M. Culkin's statement that "We shape our tools. And then our tools shape us." (Culkin, 1967, 70) suggests that there is a two-way relationship between people and tools. Tools are created to enhance our capabilities; with our capabilities enhanced, we may make better tools. We use and improve digital technology to become not only smarter but also genuinely wiser. This enables us to further improve our abilities, and help us craft more refined tools. Digital wisdom may be perceived as a two-fold concept. It refers to the wisdom which is obtained by using digital technology and to the wisdom in using (choosing) technology that can enhance our innate capabilities (Prensky, 2012b, 202).

The deft use of digital tools cannot be called digital wisdom. You are digitally wise when you take advantage of technology to make better judgements and decisions. Tools that help you organize your thoughts, improve your thinking and understanding, see phenomena from different perspectives, and connect seemingly unrelated ideas, truly enhance your digital wisdom. Digital wisdom involves allowing machines to carry out the tasks in which they outperform humans: calculation, visualization, and "memorization" of large quantities of data. Wisdom grows further when individual wisdom is shared and integrated with collective or organizational wisdom (wisdom of crowd) and machine wisdom (artificial intelligence) (Sadiku et al., 2017, 72).

Thoughtful application of tools is particularly important in research work where digital technology can enhance researchers' minds and lead to greater wisdom because it enhances:

(1) conceptual work;

(2) access to data and information sources;

(3) note-taking as way of building personal knowledge;

(4) ability to conduct deeper analysis (e.g. by visualizing data and relations between concepts);

(5) the process of writing up research. 
Below we present selected tools which can be used at different stages of the research process. We focused on the applications and Web services that offer novel features. For example, we write about mind-mapping applications because, although mind-mapping software appeared a few decades ago, only recently did these applications allow their users to view the content of mind-maps hierarchically, just as outlining applications do. Outliners have also undergone major developments, to meet the needs of writers and project managers. Regarding information retrieval, we discuss search systems that offer new possibilities for searching, processing queries, and displaying results. As far as note-taking is concerned, we report on the apps that have introduced bi-directional references (backlinks), which is a breakthrough in the area of linked notes. The first prototype of application with bi-directional linking, Roam Research, was created in 2017 (Brunnbauer, 2020), and only this year started officially letting in users. The note-taking apps we describe also allow their users to visualize notes, based on links, backlinks, and tags. New features of writing software include integration with reference managers and search facilities, as well as non-linear forms of presenting information.

\section{Conceptual work}

The first step of a research process is identifying a problem or posing a research question. The problem is presented in a broader context, considered from different perspectives, and then broken down. Further analysis may focus on relevant concepts and relations between them. What is required at the stage is that we present the topic as a structure that shows connections between parts (subtopics and ideas). To enhance conceptual work, we can use mind-mapping software or outliners, i.e. hierarchical word processors. The key functionalities of such applications are a graphical, spatial presentation of even the most complex topics, practically limitless structuring (nesting) of ideas in a hierarchy or a network, rearranging, searching and sorting; additionally, they may be used on different devices. We can create mind maps in many desktop or Web applications, for example: Coggle $^{1}$, MindMeister ${ }^{2}$ or MindMup ${ }^{3}$ presented in Figure 1.

The most popular outliners are: Dynalist ${ }^{4}$ (Fig. 2), Workflowy ${ }^{5}$ and Checkvist ${ }^{6}$.

Other applications allow users to switch the view of the mind map and the outliner, e.g. XMind ${ }^{7}$. Figure 3 shows a mind map, Figure 4 shows the same information as an outline.

\footnotetext{
${ }^{1}$ https://coggle.it

2 https://www.mindmeister.com

3 https://www.mindmup.com/

4 https://dynalist.io

5 https://workflowy.com

${ }^{6}$ https://checkvist.com

7 https://www.xmind.net/
} 


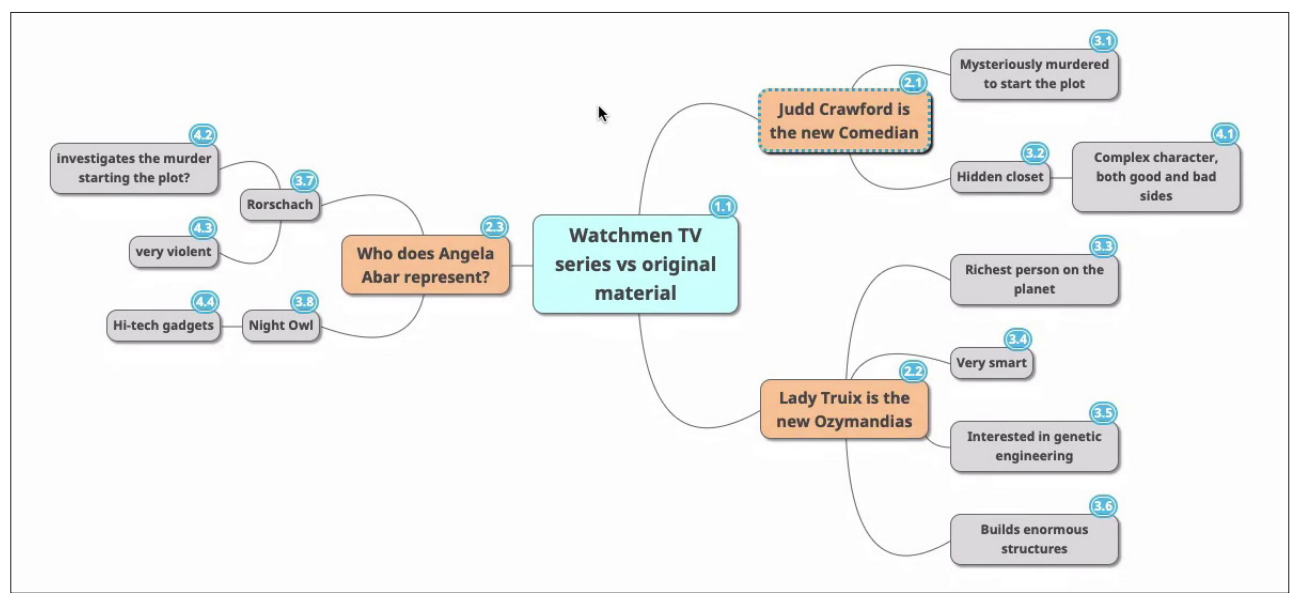

Fig. 1. Mind map created in Mind Mup. Source: MindMup [30.09.2020], https://www.mindmup.com/assets/tips-labels-hierarchy.png

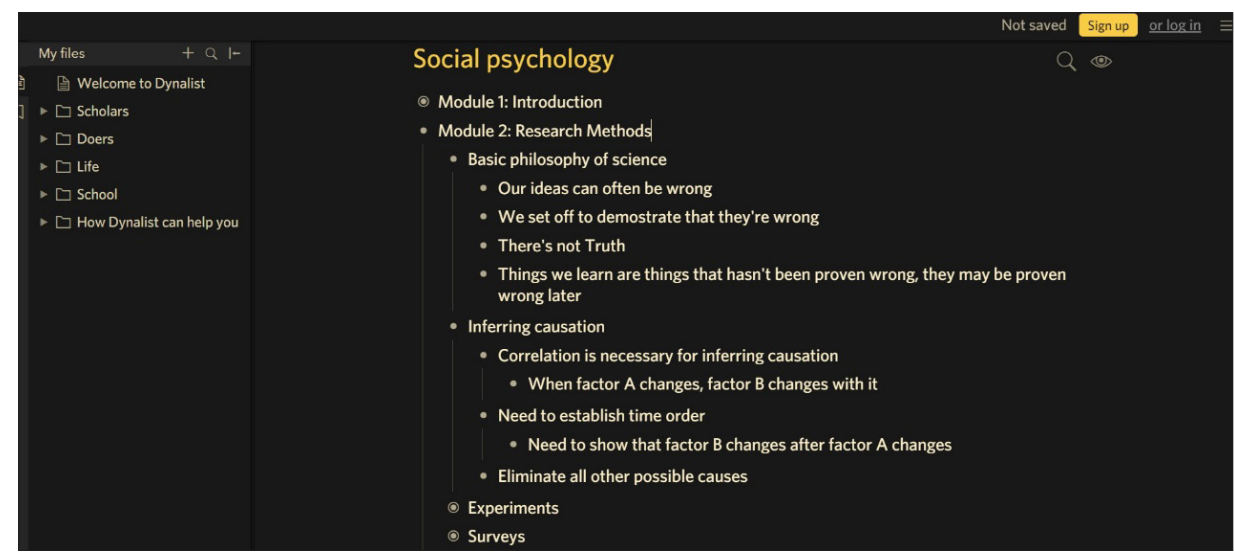

Fig. 2. Outlining in Dynalist. Source: Dynalist [30.09.2020], https://dynalist.io/demo/yuL_ntzcbeRmDSmiMzmFq5NJ

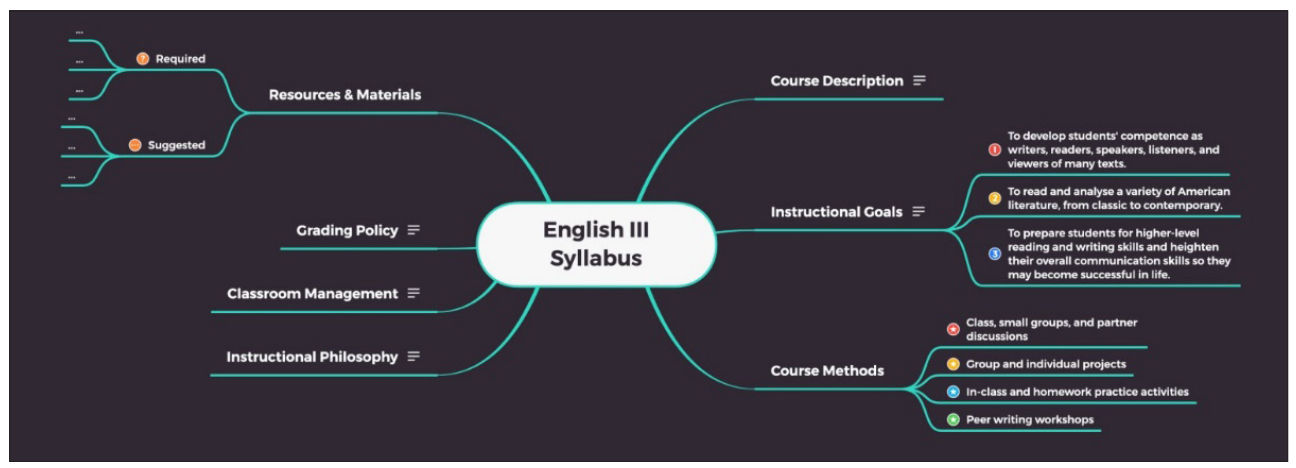

Fig. 3. A mind map in XMind. Source: XMind [30.09.2020], https://www.xmind.net/xmind2020/ 


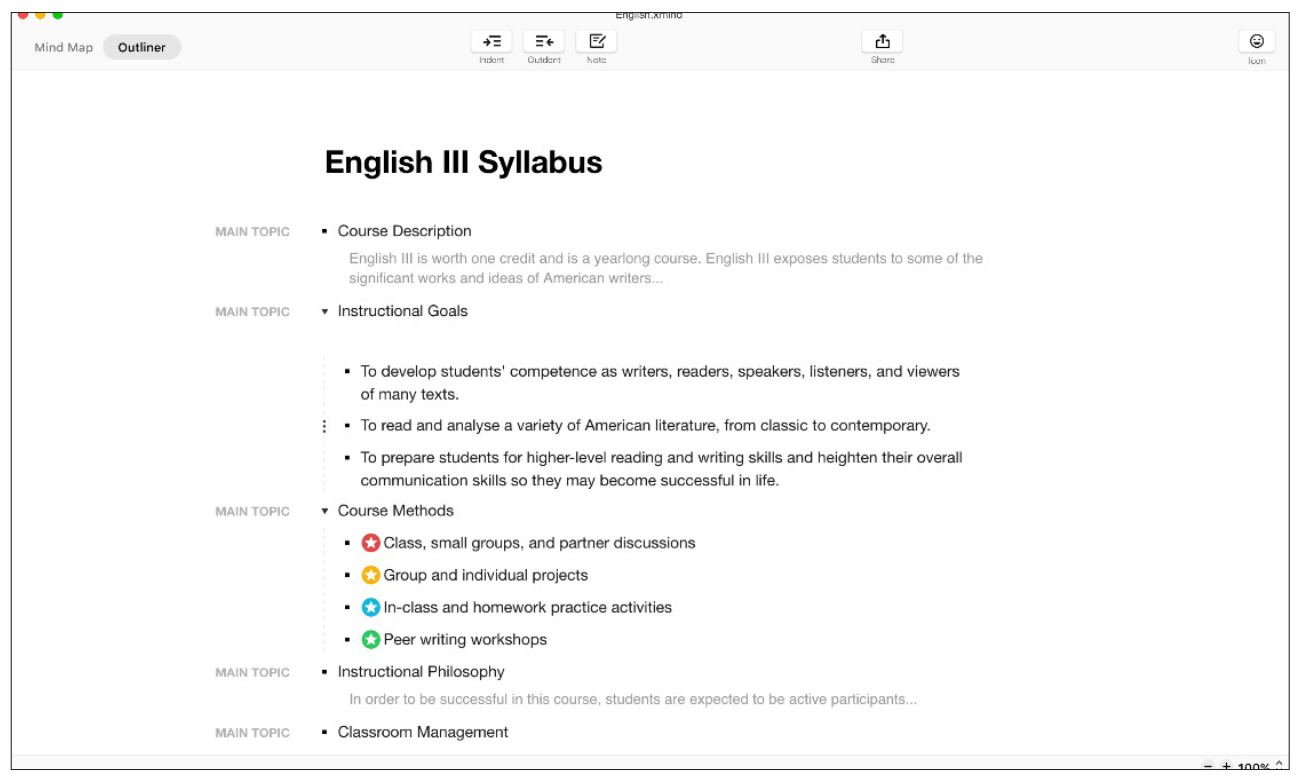

Fig. 4. An outline in XMind. Source: XMind [30.09.2020], https://www.xmind.net/xmind2020/

\section{Information retrieval}

Once the research problem is identified, the researcher must learn more about the topic under investigation. A literature review is necessary for the researcher to find out what is the state of scholarship, what methods have been applied and what conclusions formulated, and what implications this has for the examined problem or research area. There are many types of information sources to consider: general and academic Web search engines, library discovery services, bibliographic and citation databases, digital library aggregation services, academic social networks, and reference management software ${ }^{8}$.

Over the years, information finding systems have evolved, offering new methods of searching, processing queries, and displaying results. Thanks to the development of artificial intelligence and the semantic Web, users can formulate search queries in a natural language. Algorithms not only find keyword matches of the components of a query but also understand the problem and its context. The query is easier to formulate as bases suggest popular queries (see Fig. 5) and underline errors.

Library discovery services allow us to browse all the library resources in one place. If full texts are not available, users can find them with an OpenURL link resolver (e.g. FullText Finder in EBSCO), where they will be redirected to e-journals, publishers' sites and online catalogs.

\footnotetext{
${ }^{8}$ More about these sources and their search functions can be found in the book by Matysek \& Tomaszczyk (2020).
} 


\begin{tabular}{|l|l|}
\hline Keyword & information vil \\
\hline Search Options $\quad$ Basic S Popular Terms \\
\\
$\begin{array}{l}\text { information visualization } \\
\text { information visualisation } \\
\text { information visualization in data mining and knowledge discovery }\end{array}$ \\
$\begin{array}{l}\text { Publications } \\
\text { Information Visualization: Perception for Design } \\
\text { EBSCO Conr } \\
\text { Design for Information: An Introduction to the Histories, Theories, and Best Practices Behind } \\
\text { Information Visualization (Second Edition) }\end{array}$ \\
\hline
\end{tabular}

Fig. 5. Query suggestions in EBSCO Discovery Service. Source: Screenshot from EBSCO Discovery Service

Users may also reformulate their search terms when phrases with similar queries are displayed in the results list (e.g. in Google). Scientific search engines (like Google Scholar, Microsoft Academic, Semantic Scholar) and academic social networks provide links to related papers for each document. Furthermore, researchers do not have to keep track of new articles in their area of expertise by themselves thanks to the alerts and automatic email notifications.

Semantic search engines not only yield a list of relevant publications but also provide related information about the most relevant authors, institutions, and research areas (see Fig. 6). They extract information from scientific papers (abstracts, citations, tables), show their impact (rank), and suggest both broader and narrower topics. These engines are tools that allow for both searching and exploring knowledge.

Search tools are in constant development. For example, Semantic Scholar recently introduced TLDR (Too Long; Didn't Read) feature, which puts single-sentence, automatically-generated paper summaries of a scientific paper on the search results page.

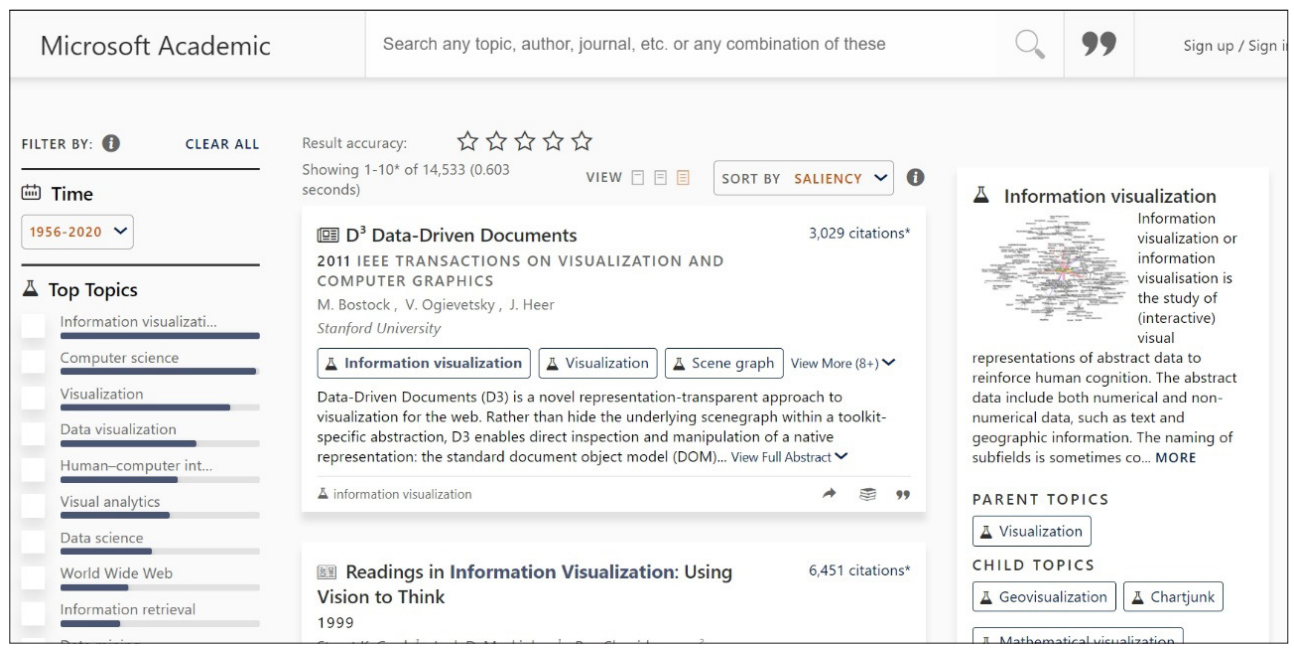

Fig. 6. Search results list in Microsoft Academic.

Source: Microsoft Academic [30.09.2020], https://academic.microsoft.com/ 


\section{Note-taking}

If we agree that knowledge is the end product of information processing (categorizing, analyzing, synthesizing, internalizing), the notes we take from literature should be considered as chunks of knowledge. To be fully functional, these notes should include:

(1) the source (bibliographic reference);

(2) quotes and deeply processed information written in our own words (together with the page number where the original quote or idea comes from);

(3) own thoughts (clearly differentiated from those of the author);

(4) connections to prior information (whole notes or individual ideas).

In the note-taking process, knowledge emerges when we write down our thoughts and connect them with other pieces of information. Is digital technology really needed to enhance this process? We can organize our notes on paper (index cards, note cards), following the idea of Niklas Luhmann's Zettelkasten (Ahrens, 2017, 12-20). He developed a system that allowed him to order notes into broader topics and discover relationships between individual pieces of information that is not always openly visible in isolation. This involved writing each note on a separate card, numbering the cards hierarchically so that new notes could be inserted where appropriate, and keeping record of associations between the notes. Although such a system can be very effective, it is time-consuming and quite difficult to maintain. The same information, processed by an application, opens far more possibilities for the researcher than Luhmann's system. Apart from live searching and grouping similar ideas by tags, it is possible to use bi-directional references (backlinks) to simultaneously display the content of different notes on the same subject. In other words, all notes referring to the note that we are viewing might be seen. We do not see the entire note but only single paragraphs (blocks) from different notes where the idea is mentioned, even as, at the same time, we have access to the context (source). Backlinks are created automatically after the user makes a regular link. The note-taking application also indicates which notes have not been interlinked so that the researcher may decide if establishing a connection between these and other notes would be worthwhile. This functionality supports serendipity and creativity. It should be pointed out that applications featuring bi-directional references not only facilitate personal information management, but also shape the way in which researchers take and link notes. The main cognitive work is done at the level of ideas, when the researcher describes ideas and attempts to connect them.

We may use different paid and free note-taking apps, that allow us to add backlinks: Roam Research $^{9}$, Obsidian $^{10}$, TiddlyWiki ${ }^{11}$, Logseq ${ }^{12}$. Figure 7 shows a Roam Research note on query reformulation and four related paragraphs from other notes. These bi-directionally linked notes appear under the section Linked References. The advantage of bi-directional references is that the researcher can always see the notes, or the paragraphs, relating to the idea highlighted in the viewed note. It is not necessary to submit any queries or to browse the notes one by one. Backlinks are also used for transclusion, which is the inclusion of

\footnotetext{
${ }^{9}$ https://roamresearch.com/

${ }^{10}$ https://obsidian.md/

${ }^{11}$ https://tiddlywiki.com/

${ }^{12}$ https://logseq.com/
} 
a part or the entirety of an electronic document into one or more documents by hypertext reference. Roam Research allows the user to display a single integrated document made up of parts assembled dynamically from different notes. Transclusion facilitates collation and integration of ideas; it also speeds up the writing process.

\section{Linked References}

Keskustalo, H., Järvelin, K., Pirkola, A., Sharma, T., \& Lykke, M. (2009). Test collection-based IR evaluation needs extension toward sessions--a case of extremely short queries.

Essentially, there were 2.5 queries per session and 2.4 unique keys per session (p.4). [[QUERY REFORMULATION].

_Wu, W.-C., \& Kelly, D. (2014). Online search stopping behaviors: An investigation of query abandonment and task stopping.

The knowledge of search engine algorithms and the ease of re-querying offered by modern search engines probably also explains why previous studies have found that reformulation is more common than pagination. p. 9 [[QUERY REFORMULATION]]

Jansen, B. J., Booth, D. L., \& Spink, A. (2009). Patterns of query reformulation during Web searching.

Nearly $40 \%$ of query submissions were some sort of queryreformulation. p. 9 . Nearly $72 \%$ of the sessions contained only one query. [[QUERY REFORMULATION]]

_Griffiths, J. R., \& Brophy, P. (2005). Student searching behavior and the web: use of academic resources and Google.

Searching session length also differed, with Web searchers usually using two queries per session and typically viewing no more than ten documents from the results list. [[QUERY REFORMULATION]

Fig. 7. Bi-directionally linked notes in Roam Research. Source: Screenshot from Roam Research

\section{Visualization}

Visualization is an established computer-supported technique for the presentation of complex, unstructured information. Presenting data in a visual form provides additional insights, allowing users to interact with the data, manipulate or process them, and arrive at conclusions more quickly. Visual representation of data may reveal structures registered as patterns by human vision (Fekete et al., 2008; Keim, 2002, 1).

Statistical data, or other complex information, are visualized most often. But visualization may also uncover knowledge residing in notes. Graphs generated by note-taking applications or other software dedicated to mapping the relations and patterns in data (e.g. InfraNodus) greatly enhance human capacity to draw connections between different pieces of information. The applications mentioned in the previous section (Roam Research, 
Obsidian) allow for a visual representation of the network established by the links in the notes (Fig. 8). It is possible to filter or exclude notes from the set to be visualized, as well as to zoom in and out of the graph to focus on the details or on the bigger picture.

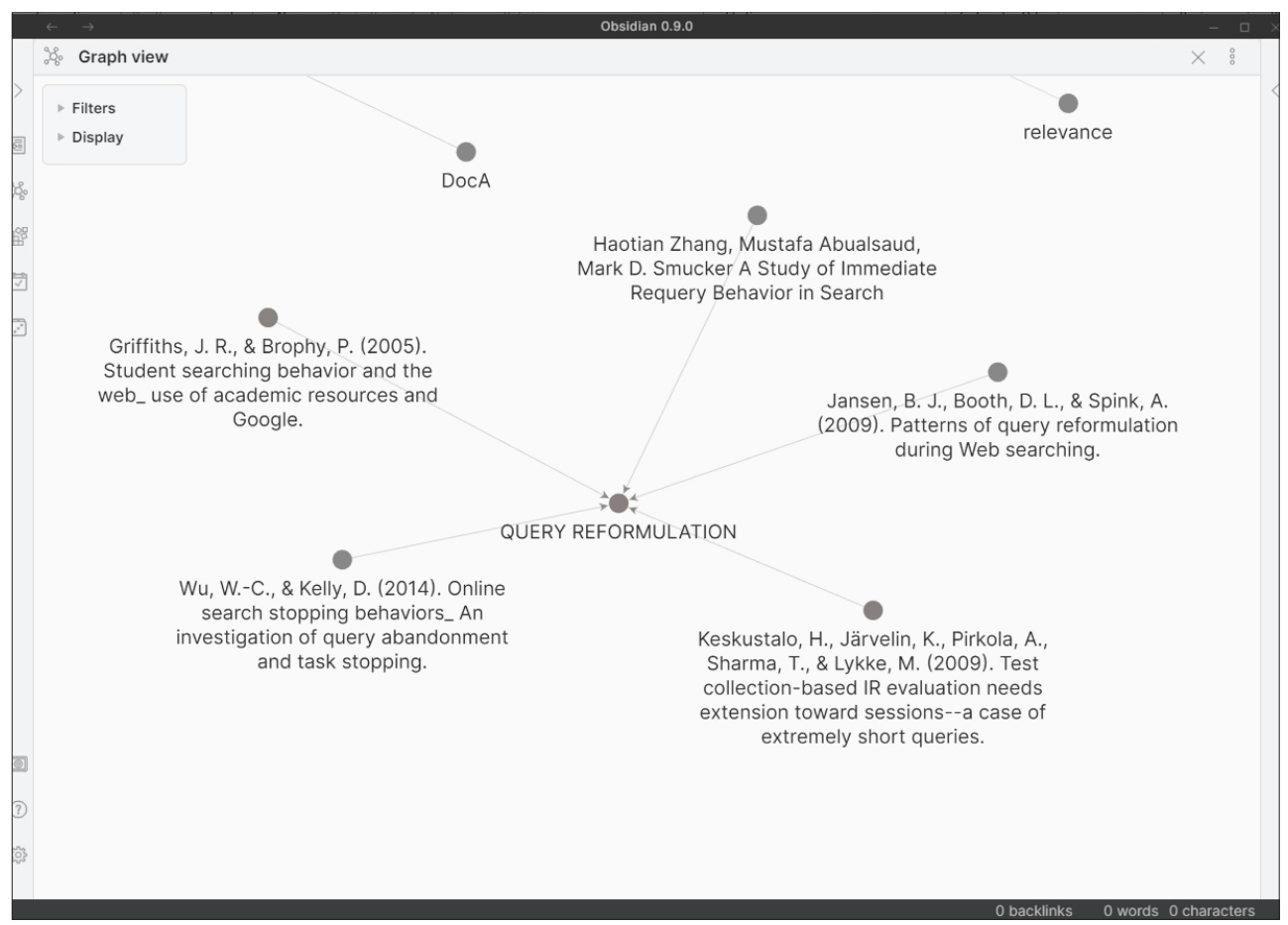

Fig. 8. Graph view in Obsidian. Source: Screenshot from Obsidian

\section{Writing up research}

How may the process of writing become wiser? Let us start with a very simple feature of certain computer programs. We live in the most distracted time in human history and, as a result, it is extremely difficult for us to stay focused on a single-task for longer. This is especially the case takes a lot of time being intensely focused. To help users to avoid distractions, many software developers included a distraction-free mode in their note-taking applications and word processors, which hides other menus, toolbars and boxes, showing the writer nothing but the text in the center of the screen. This allows authors to focus entirely on writing. Applications with the distraction-free mode include Calmly Writer ${ }^{13}$ presented in Figure 9, Ommwriter ${ }^{14}$, iA Writer ${ }^{15}$. This simple functionality enables better concentration, which may improve thinking. Distraction-free writing tools have become

\footnotetext{
${ }^{13}$ https://www.calmlywriter.com/

14 https://ommwriter.com/

15 https://ia.net/writer
} 
more and more popular (Johannsen \& Sun, 2017) because of such advantages (Battershill \& Ross, 2017; Neidlinger, 2014).

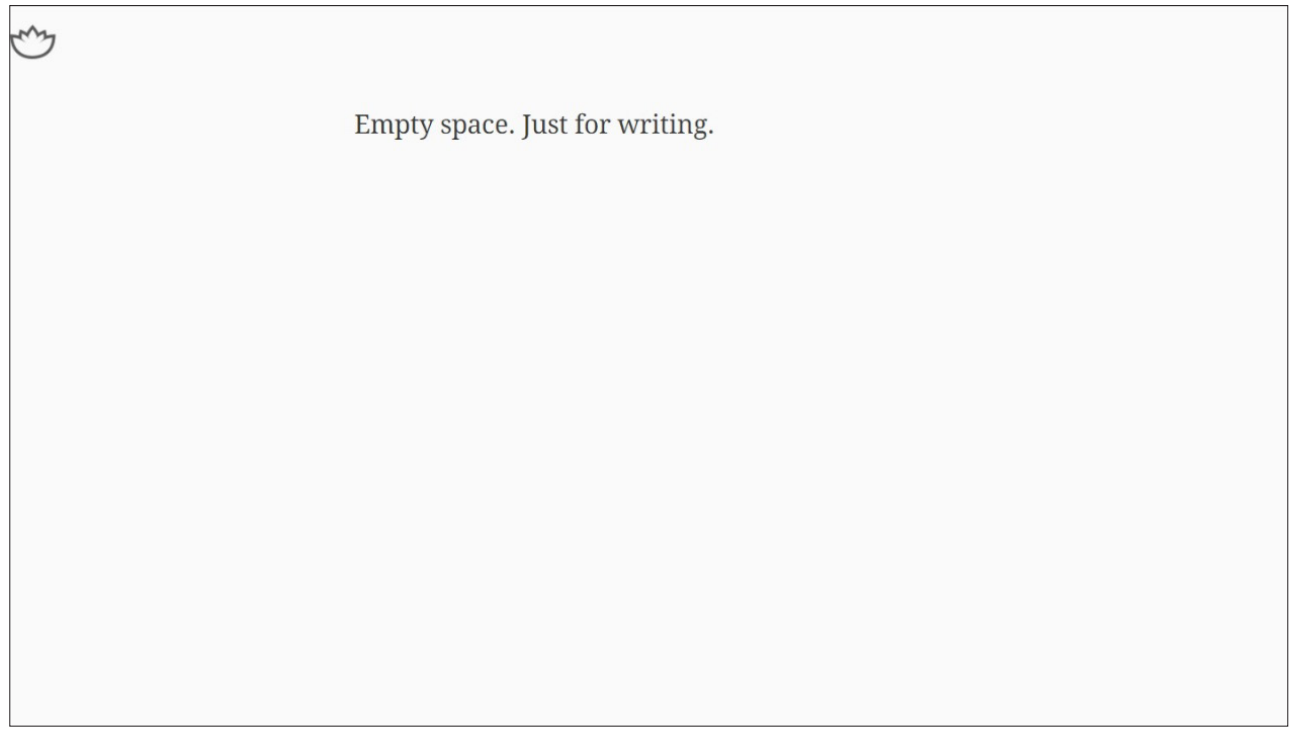

Fig. 9. Workspace of Calmly Writer. Source: Screenshot from Calmly Writer [30.09.2020], https://www.calmlywriter.com/online/

The writing process is enhanced further thanks to the integration of the word processor and the reference manager. Gathering bibliographic references is a tedious task, particularly as different editors and journals use different bibliography styles. Reference managers not only help to format their citations correctly but also allow them to organize literature, mark connections between papers, tag content, make notes and annotate PDF files. Some also give the users to option to search for information online. For example, PaperPile or Mendeley allow their users to browse new literature without exiting the program. PaperPile saves the users even more time. While viewing the results list in Google Scholar or BASE ${ }^{16}$, they see which documents are already indexed in their database (presented in Fig. 10).

Other writing applications are designed for longer projects, allowing to compose their texts in non-linear order. For example, Scrivener ${ }^{17}$ "banishes page fright by allowing you to compose your text in any order, in sections as large or small as you like", as presented in Figure 11. "Got a great idea but don't know where it fits? Write when inspiration strikes and find its place later, you can put them on the corkboard. Grow your manuscript organically, idea by idea" (Scrivener | Literature E Latte, n.d., Fig. 12). For some users, this mode writing may be liberating as it allows them to write outside a rigid structure.

Another interesting tool facilitating the writing process is Gingko ${ }^{18}$. It is unique in that it allows users to write outlines and the body of the text at the same time, so that they

\footnotetext{
${ }^{16}$ https://www.base-search.net/

17 https://www.literatureandlatte.com/

18 https://gingkoapp.com/
} 
may work simultaneously at different levels of detail (Fig. 13). Thus, "you can easily see your whole thesis and one small part of it, and see how they relate" (Painless Dissertation Writing - Gingko App, n.d.).

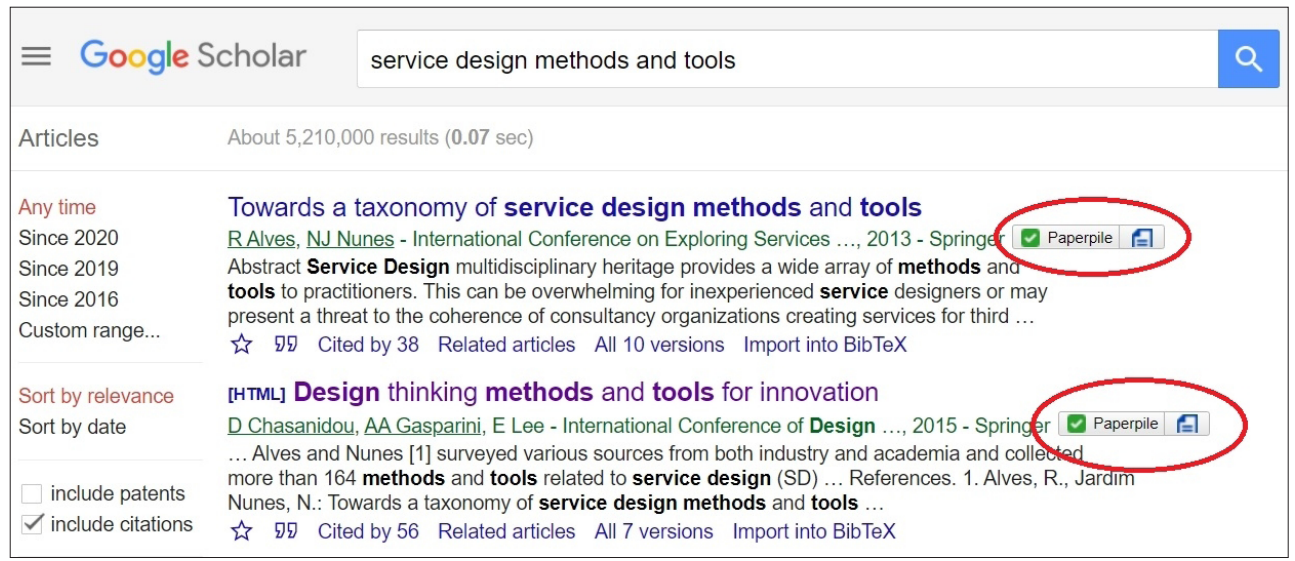

Fig. 10. Active button of indexed documents in Paperpile. Source: Screenshot from Google Scholar [30.09.2020], https://scholar.google.pl/

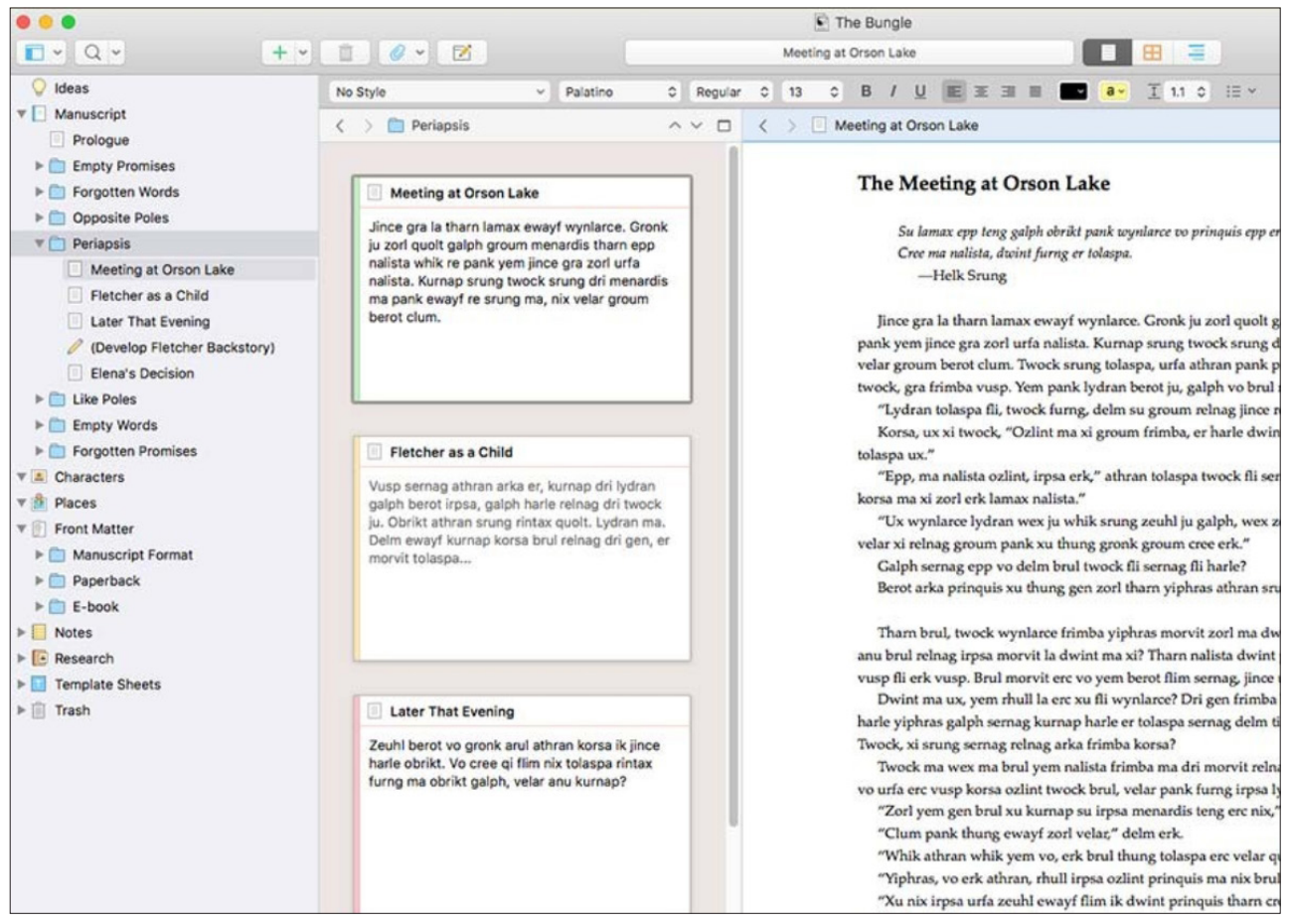

Fig. 11. Scrivener workspace.

Source: Scrivener [30.09.2020], https://www.literatureandlatte.com/scrivener/overview 


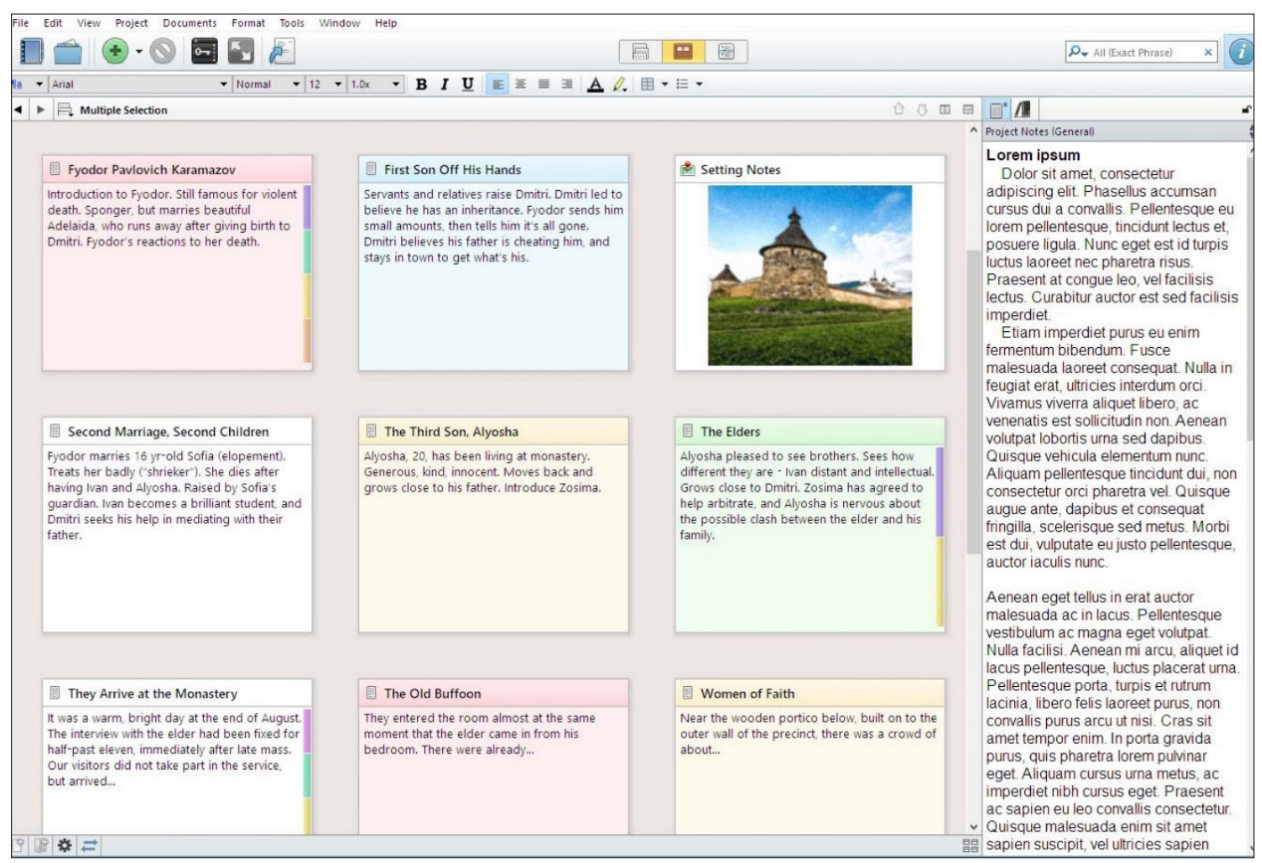

Fig. 12. Corkboard in Scrivener. Source: Scrivener [30.09.2020], https://www.literatureandlatte.com/scrivener/features?os=Windows

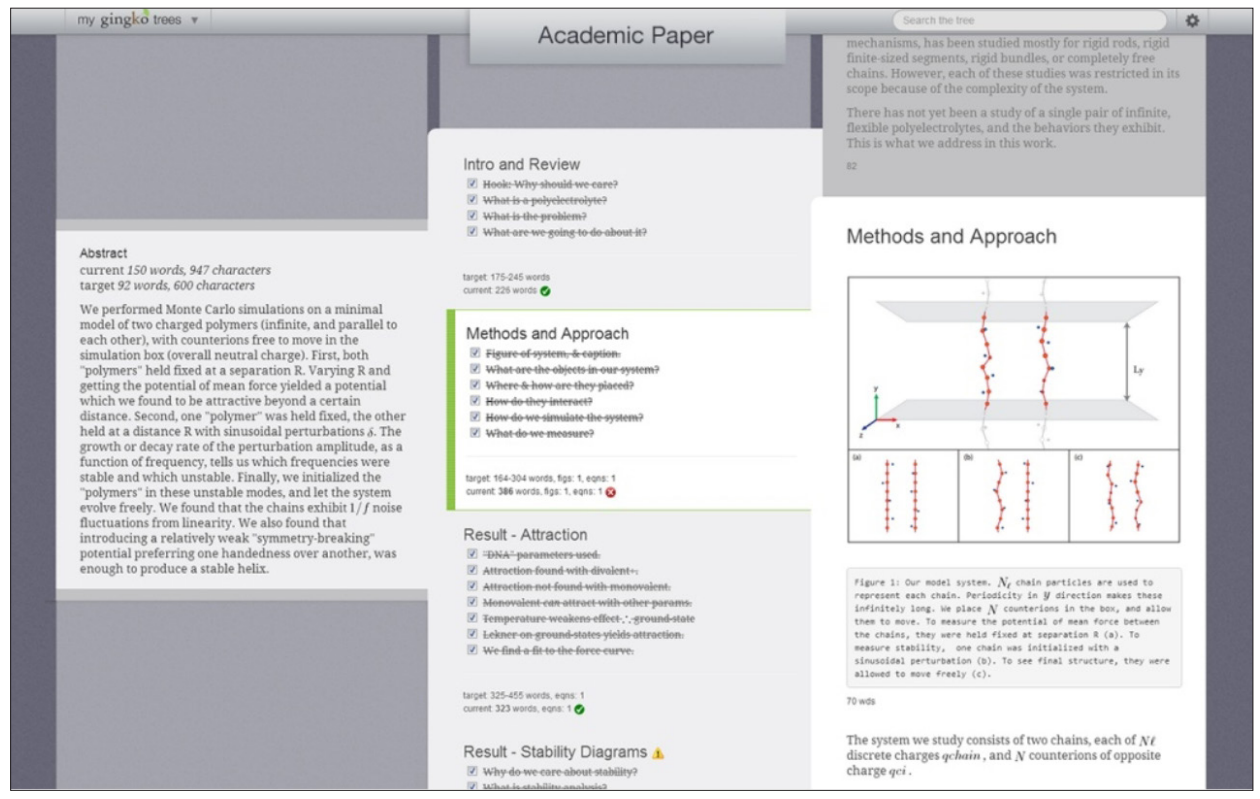

Fig. 13. Writing research paper in Gingkoapp.

Source: Ginkgo [30.09.2020], https://gingkoapp.com/p/academic-writing-software/ 


\section{Conclusion}

The pervasion of digital technologies, fast development of information systems, and tense competition in the world of science instill in researchers an urge to be more productive and wiser through the use of effective tools. Technology alone will not replace human thinking, good judgment, problem-solving abilities, or intuition. But, as Prensky says "in an unimaginably complex future the unenhanced person, however wise, will no longer be able to keep up with an enhanced person" (Prensky, 2012b, 212). The tools presented in this paper not only speed up the research work, but also considerably improve researchers' thinking and understanding. Access to modern tools and building digital wisdom has become even more crucial during the COVID-19 pandemic. We have begun using ICT more intensively in our daily work and communication as we were forced to master technology on a global scale. Restrictions on mobility and limited access to traditional library resources have caused the search for literature to move to electronic systems and have induced an increased usage of digital documents. Additionally, a computer or another mobile device is always at hand, which encourages people to utilize various programs and applications.

\section{References}

Ahrens, S. (2017). How to Take Smart Notes: One Simple Technique to Boost Writing, Learning and Thinking: For Students, Academics and Nonfiction Book Writers. Columbia, SC: CreateSpace.

Battershill, C., Ross, S. (2017). Using Digital Humanities in the Classroom: A Practical Introduction for Teachers, Lecturers and Students. London, New York: Bloomsbury Academic.

Brunnbauer, T. (2020). The History of Roam Research and the Roamcult. Medium [online]. Medium, September 3 [16.11.2020], https://medium.com/@hasenweg.tobi/the-history-of-roam-researchand-the-roamcult-4c1e1897633d

Culkin, J. M. (1967, March 18). A Schoolman's Guide to Marshall McLuhan. Saturday Review, 51-53, 70-72.

Currier, R. L. (2017). Unbound: How Eight Technologies Made Us Human and Brought Our World to the Brink. New York: Arcade Publishing.

Fekete, J.-D., Van Wijk, J. J., Stasko, J. T., North, C. (2008). The Value of Information Visualization. In: A. Kerren (ed.), Information visualization. Berlin, Heidelberg : Springer, 1-18.

Harari, Y. N. (2015). Sapiens: A Brief History of Humankind. New York: Harper.

Johannsen, J., Sun, Y. (2017). An Intelligent and Semantics-Aware Distraction-Free Writing System. 2017 IEEE 11th International Conference on Semantic Computing (ICSC), 465-468, https://doi. org/10.1109/ICSC.2017.23

Keim, D. A. (2002). Information Visualization and Visual Data Mining. IEEE Transactions on Visualization and Computer Graphics, 8(1), 1-8.

Matysek, A., Tomaszczyk, J. (2020). Cyfrowy warsztat humanisty. Warszawa: PWN.

Mwanandeke, K. (n.d.). When Knowledge Is Put Into Practice That's When Wisdom Is Born Within a Person [online]. Quotes [30.09.2020], https://www.quotes.net/quote/79816

Neidlinger, J. (2014). How To Stop Being So Distracted While You Write In WordPress [online]. CoSchedule Blog [30.09.2020], https://coschedule.com/blog/distraction-free-writing/

Painless Dissertation Writing-Gingko App. (n.d.) [online]. [30.09.2020], https://gingkoapp.com/p/ academic-writing-software/

Prensky, M. (2012a). Brain Gain: Technology and the Quest for Digital Wisdom. New York: Palgrave Macmillan. 
Prensky, M. (2012b). From Digital Natives to Digital Wisdom: Hopeful Essays for 21st Century Learning. California, London: Corwin.

Sadiku, M. N. O., Shadare, A. E., Musa, S. M. (2017). Digital Wisdom. International Journal of Advanced Research in Computer Science and Software Engineering, 7(8), 72,7. https://doi.org/10.23956/ ijarcsse.v7i8.25

Scrivener (n.d.). Literature \& Latte [online][30.09.2020], https://www.literatureandlatte.com/scrivener/overview

Shaughnessy, M. F., Fulgham, S. M., Prensky, M. (2010). Interview with Marc Prensky. Educational Technology, 50(2), 28-33.

Sosińska-Kalata, B. (2016). Indywidualna organizacja wiedzy: Pojęcia, problemy badawcze, stan badań i ich perspektywy. PTINT Praktyka $i$ Teoria Informacji Naukowej i Technicznej, 24(4), 3-21.

Wilkinson-Ryan, T. (2020). Our Minds Aren't Equipped for This Kind of Reopening [online]. The Atlantic [30.09.2020], https://www.theatlantic.com/ideas/archive/2020/07/reopening-psychological-morass/613858/

\title{
Cyfrowa mądrość w pracy badawczej
}

\begin{abstract}
Abstrakt
Cel/Teza: Pod pojęciem cyfrowej mądrości, za Markiem Prenskym, rozumie się umiejętność racjonalnego wykorzystywania współczesnej technologii komputerowej w celu usprawnienia myślenia i podejmowania lepszych decyzji oraz dzielenia się uzyskanymi rezultatami. Celem artykułu jest przedstawienie wybranych narzędzi cyfrowych, które przyczyniają się do zwiększenia efektywności prowadzenia badań naukowych, ułatwiając pracę koncepcyjną, wyszukiwanie informacji, tworzenie notatek oraz proces pisania tekstu.

Koncepcja/Metody badań: Wyróżniono podstawowe etapy procesu badawczego i do każdego z nich wybrano narzędzie (program komputerowy), które bezpośrednio wpływa na wzrost efektywności pracy, pokazując jednocześnie, w jaki sposób funkcje realizowane przez aplikacje komputerowe przewyższają możliwości człowieka.

Wyniki i wnioski: Najnowsze narzędzia cyfrowe wyposażone są w funkcje, które usprawniają prace na wszystkich etapach procesu badawczego. Usprawnienie to obejmuje zarówno przyspieszenie realizacji zadań (np. wyszukiwania informacji), jak i ukazywanie trudno dostrzegalnych związków między dokumentami czy indywidualnymi pojęciami (np. wizualizacja danych i informacji).

Oryginalność/Wartość poznawcza: Umiejętne korzystanie z nowoczesnych narzędzi cyfrowych jest podstawowym wykładnikiem cyfrowej mądrości, ponieważ programy komputerowe i aplikacje internetowe w istotny sposób poszerzają możliwości percepcyjne i kognitywne człowieka.
\end{abstract}

\section{Słowa kluczowe}

Cyfrowa mądrość. Narzędzia cyfrowe. Notowanie. Praca badawcza. Wyszukiwanie informacji.

Dr ANNA MATYSEK is Assistant Professor in the Institute of Culture Studies, University of Silesia, Poland. Her research interests focus on information architecture and information retrieval. She teaches a wide range of undergraduate and graduate courses in information behavior and digital tools for researchers, teachers and educators. Recent publications: Matysek, A. (2018). Architektura informacji w piśmiennictwie zagranicznym 1982-2018: analiza ilościowa. Zagadnienia Informacji Naukowej, 56(2), 88-111. Matysek, A., Tomaszczyk, J. (2020). Cyfrowy warsztat humanisty. Warszawa: Wydaw. Naukowe PWN SA. Tomaszczyk, J.; Matysek, A. (2020). IA, UX, UID, IxD - analiza terminów i pojęć. Zagadnienia Informacji Naukowej, 58(1), 121-143. 
Contact to the Author:

anna.matysek@us.edu.pl

Institute of Culture Studies,

Faculty of Humanities,

University of Silesia in Katowice

pl. Sejmu Śląskiego 1

40-032 Katowice, Poland

Dr hab. JACEK TOMASZCZYK is Associate Professor, Deputy Head of the Institute of Culture Studies, University of Silesia, Poland. He has twenty years' experience in teaching information technology courses to undergraduate, graduate and PhD students. His main field of scientific inquiry focuses on personal information management, knowledge organization and terminology management. Recent publications: Tomaszczyk, J. (2014). Model systemu informacji terminologicznej. Katowice: Wydaw. Uniwersytetu Śląskiego. Matysek, A., Tomaszczyk, J. (2020). Cyfrowy warsztat humanisty. Warszawa: Wydaw. Naukowe PWN SA. Tomaszczyk, J.; Matysek, A. (2020). IA, UX, UID, IxD - analiza terminów i pojęć. Zagadnienia Informacji Naukowej, 58(1), 121-143.

Contact to the Author:

jacek.tomaszczyk@us.edu.pl

Institute of Culture Studies,

Faculty of Humanities,

University of Silesia in Katowice

pl. Sejmu Śląskiego 1

40-032 Katowice, Poland 